Results Lung tissue treated with CSE showed a dose-dependent increase in IL-8 and MMP-9 secretion across a range $0.6250 \%-20 \%$ CSE. IL-8 response to 20\% CSE was $71592.21 \mathrm{pg} / \mathrm{mg} / \mathrm{ml} \pm 4680.7 \mathrm{SE}$ compared to non-stimulated tissue $14177 \mathrm{pg} / \mathrm{mg} / \mathrm{ml} \pm 1088 \mathrm{SE}$ ( $\mathrm{n}=6, \mathrm{p}<0.001$ ), MMP-9 response to $20 \%$ CSE $206 \mathrm{pg} / \mathrm{mg} / \mathrm{ml}$ $\pm 30.55 \mathrm{SE}$ vs control $104 \mathrm{pg} / \mathrm{mg} / \mathrm{ml} \pm 4.49 \mathrm{SE}$ ( $\mathrm{n}=6, \mathrm{p}<0.001$ ). However no demonstrable rise in TNF- $\alpha$ secretion from tissue treatedwith CSE was detectable. With LPS stimulation both TNF- $\alpha$ and IL-8 responses demonstrated adose-dependent increase within the range $0.01-100 \mathrm{ng} / \mathrm{ml}(\mathrm{n}=5, \mathrm{p}=0.0003)$.

Treatment effects Stimulated IL-8 and MMP-9 secretion was significantly reduced in tissue treated with $0.1 \%$ vitamin C. $25 \%$ reduction in IL8 $(n=3, p=0.065)$ and $32 \%$ reduction in MMP9 $(n=3$, $p=0.0133$ ). Fluticasone treatment reduced LPS induced TNF- $\alpha$ and IL-8 in a dose dependent manner $(n=4, p=0.03)$.

Conclusions A human lung tissue model of smoke and LPS induced inflammation demonstrates the importance of selecting appropriate readouts for a given stimulus or treatment and hence a potential utility in selecting trial endpoints. Furthermore it demonstrates that vitamin $\mathrm{C}$ and corticosteroids can reduce oxidative stress and inflammation in a complex tissue system- their combined effects warrant investigation in COPD.

\section{P117 3D CRYO-ELECTRON MICROSCOPIC ANALYSIS OF THE DISEASE MECHANISM OF $\alpha 1$-ANTITRYPSIN DEFICIENCY}

doi:10.1136/thoraxjnl-2011-201054c.117

${ }^{1} B$ Gooptu, ${ }^{1} Y$ Chaban, ${ }^{2} \mathrm{~J}$ A Irving, ${ }^{1} \mathrm{D}$ K Clare, ${ }^{2} \mathrm{D}$ A Lomas, ${ }^{1} \mathrm{E}$ Orlova, ${ }^{1} \mathrm{H}$ R Saibil. ${ }^{1}$ Institute of Structural and Molecular Biology, Department of Biological Sciences, Birkbeck College, University of London, London, UK; ${ }^{2}$ Department of Medicine, University of Cambridge, Cambridge Institute for Medical Research, Cambridge, UK

$\alpha_{1}$-antitrypsin deficiency is characterised by predispositions to liver disease and severe, early-onset emphysema. It is caused by point mutations that destabilise the molecular structure of $\alpha_{1}$-antitrypsin, leading it to self-associate into chains known as polymers. Polymerisation abolishes the antiprotease activity of $\alpha_{1}$-antitrypsin and causes circulating deficiency of the protein. These loss-of-function effects result in dysregulated elastase activity within the lung parenchyma. In addition, polymerisation has pro-inflammatory gain-of-function effects that must be mediated through the structural characteristics of the polymer itself. It is therefore important to understand the structure of the $\alpha_{1}$-antitrypsin polymer to identify targets for drug design. We have used cryo-electron microscopy, single particle reconstruction techniques to study $\alpha_{1}$-antitrypsin polymers. Analysis of the 3D arrangement of $\alpha_{1}$-antitrypsin molecules within the directly observed polymer chain allows us to evaluate current competing models of polymer assembly.

\section{P118 THE ROLE OF THE RETINOIC ACID PATHWAY IN HUMAN LUNG REGENERATION}

doi:10.1136/thoraxjnl-2011-201054c.118

J P Ng-Blichfeldt, M Griffiths, U Griesenbach, B Allen, M Hind. Imperial College London, London, UK

Recent studies into retinoic acid (RA)-induced alveolar regeneration in rodent models of emphysema and bronchopulmonary dyplasia strongly suggest a latent regenerative potential of the adult mammalian lung. RA signalling is known to have an important role during alveolar formation in the developing lung in rodents and man. However, critical differences between animal and human physiology and development qualify the relevance of animal models of regeneration. Here we explore the role of RA signalling in human lung regeneration. Using RT-PCR with primers specific to RA signalling genes, we confirm expression of the RA synthesising enzymes Raldh1, 2 and 3, RA degrading enzymes Cyp26 A1, B1 and $\mathrm{C} 1$, retinoic acid receptors RAR- $\alpha, \beta, \gamma$ and retinoid binding proteins CRBPI and II, and CRABP I and II in normal, human peripheral lung tissue. To determine which cell types of peripheral lung are involved in RA signalling we have isolated primary alveolar type 2 epithelial cells and primary vascular endothelial cells and confirm expression of RA signalling genes. We have developed an high performance liquid chromatography (HPLC) method to identify and quantify endogenous human lung retinoids and demonstrate the ability to separate known standard retinoids by characteristic elution times. Finally, using precision cut lung slices we are developing an experimental system to determine the effects of retinoids in an architecturally complex human tissue model. Future work will include characterisation and optimisation of a primary human type 2 alveolar epithelial cell wound healing model and the effects of various selective retinoic acid receptor agonists and antagonists

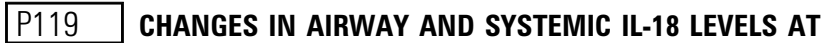 EXACERBATION IN COPD PATIENTS}

doi:10.1136/thoraxjnl-2011-201054c.119

A J Mackay, G C Donaldson, A R C Patel, R Singh, J R Hurst, J A Wedzicha. Academic Unit of Respiratory Medicine, UCL, London, UK

Introduction IL-18 is a proinflammatory cytokine implicated in COPD pathophysiology, causing pulmonary inflammation and emphysema in murine models. IL-18 receptor expression is increased on alveolar macrophages in COPD. ${ }^{1}$ IL-18 levels are elevated in serum and sputum of stable COPD patients. We hypothesised that airway and systemic IL-18 concentrations increase further at exacerbation.

Methods Sputa and sera prospectively collected from the London COPD cohort were analysed using ELISA (eBioscience ${ }^{\circledR}$, Vienna). Patients had an $\mathrm{FEV}_{1}=80 \%$ predicted and $\mathrm{FEV}_{1} / \mathrm{FVC}$ ratio $=0.7$. Baseline was defined as at least 6 weeks after, and 2 weeks before, an exacerbation. An exacerbation was defined as an increase for two consecutive days in respiratory symptoms, with at least one major symptom (dyspnoea, sputum purulence or volume) plus another major or minor (wheeze, cold, sore throat or cough) symptom. Exacerbation frequency was calculated from daily diary cards collected over the previous 12 months. When unavailable, patient's recall of exacerbations over the preceding year was used. Frequent exacerbators had $\geq 2$ exacerbations in the preceding year, infrequent exacerbators $<2$.

Results 94 COPD patients had serum analysed, of whom 48 also had sputum analysed. $60 \%$ were male, mean age was 71.6 years (SD 8.5), mean $\mathrm{FEV}_{1}$ predicted $50.6 \%$ (18.1). Sputum IL-18 levels increased significantly from baseline to exacerbation (median 1.46 $\log _{10} \mathrm{pg} / \mathrm{ml}$ (IOR 0.96-2.01) vs 1.95 (0.96-2.23), $\mathrm{n}=48, \mathrm{p}=0.023$, Abstract P119 figure 1). However, serum IL-18 concentrations were not significantly greater at exacerbation compared to paired baseline levels (median $2.17 \log _{10} \mathrm{pg} / \mathrm{ml}(1.97-2.37$ ) vs 2.08 (1.91-2.36), $\mathrm{n}=31, \mathrm{p}=0.299)$. There was no correlation between baseline serum IL-18 concentrations and exacerbation frequency $(n=94, \rho=0.096$, $\mathrm{p}=0.357$ ) or $\mathrm{FEV}_{1} \%$ predicted ( $\left.\mathrm{n}=93, \rho=0.081, \mathrm{p}=0.443\right)$. No significant difference was found in baseline serum IL-18 concentrations between frequent and infrequent exacerbators (median $148 \mathrm{pg} / \mathrm{ml}(95-235 ; \mathrm{n}=46)$ vs 120 (78-219; $\mathrm{n}=48), \mathrm{p}=0.431)$. There was no correlation between baseline serum IL-18 concentrations and paired sputum levels $(n=42, \rho=-0.149, p=0.348)$.

Conclusions Sputum but not serum IL-18 increases at COPD exacerbation. Treatment options for exacerbations are limited and there is a need for novel anti-inflammatories. The results of this study suggest IL-18 as a potential target for exacerbation therapy. 